\title{
Learning Political Theory by Role Playing
}

\section{Andrew Schaap}

Role playing is more likely to promote active learning amongst undergraduate students than a traditional university lecture. This teaching method has been employed effectively in disciplines such as history and in area-studies subjects such as Middle Eastern politics in which students assume the role of particular historical or political agents. However, it is not obvious how role playing might be used to teach political theory. In this article, I discuss a role-play exercise that I devised and consider how it helped to promote what Paul Ramsden calls a 'deep-holistic' approach to learning amongst undergraduate students in a second/third year subject in political theory.

It is the year 2050. The world is a changed place. It is now divided into four superstates - Utilitaria, Communitaria, Proletaria, Libertaria - and the tiny, fledgling state: Egalitaria. The military dominance of the Libertarians that led to the collapse of the UN in 2010 is now at an end and after the atrocities perpetrated by the Communitarians (against the rootless cosmopolitans within their territory) during the Third World War (2045-2049), the world order is in a state of flux. There is a widespread sense of opportunity for a new beginning. You have been elected by your fellow citizens of PROLETARIA to draft a new declaration of human rights and to represent your country at the inaugural meeting of the Federal Republic of Earth (FRE) at which a new declaration is to be adopted ...

Learning political theory is largely about acquiring a vocabulary that enables one to reflect more critically and precisely about the terms on which human beings (do and should) co-operate for and compete over public goods, symbolic and material. As such, political theory is necessarily abstract and general. But, competency in political theory requires an ability to move from the general to the particular and back again, not simply by applying general principles to particular events and experiences but by reflecting on and rearticulating concepts in the light of the particular. Role play is an effective technique for teaching political theory because it requires that students employ political concepts in a particular context so that learning takes place as students try out new vocabularies together with their peers and a lifelong learner in the subject: their teacher.

In this article I reflect on my attempt, as a first-time lecturer, to promote 
what Paul Ramsden calls a 'deep-holistic' approach to learning by using role play to teach political theory. I begin by surveying Ramsden's six principles of effective learning, contextualising these in relation to his 'approaches to learning' theory. I then consider the importance of role playing as an alternative to lecturing and outline a role play based on the above scenario, which is borrowed from Steven Lukes's (1993) Amnesty lecture 'Five Fables of Human Rights'. I examine the extent to which the implementation of this role play exemplified Ramsden's six principles of effective teaching and conclude by considering the particular merits of role play for teaching political theory.

\section{Teaching to promote a deep-holistic approach to learning}

According to an influential theory of teaching in higher education, people tend to approach learning either in a 'deep-holistic' or 'surface-atomistic' way (Ramsden, 1992, pp. 43ff.). Students who adopt a deep-holistic approach to learning seek to discover the meaning of an idea, text or concept by relating new information to previous experience and the broader context within which it is encountered. By contrast, students who adopt a surface-atomistic approach tend to simply reproduce information, accumulating particular facts or details without discovering and constructing relations between them. Ramsden (1992, pp. 53ff.) reports on research that shows that deep-holistic approaches to learning are related to higher-quality outcomes and greater enjoyment while surface-atomistic approaches are dissatisfying and associated with poorer grades.

Ramsden (1992, pp. 96-102) identifies six key principles of teaching in higher education to promote a deep-holistic approach to learning. Effective teaching requires: engaging student interest; demonstrating concern and respect for students and student learning; providing appropriate feedback and assessment so that students can monitor their own learning; presenting students with clear goals and an intellectual challenge; giving students independence and control over their own learning; and modifying one's own teaching practice in response to student learning outcomes. In sum, effective teaching encourages students to relate to the subject material in a purposeful way. Teaching methods that promote deep-holistic approaches to learning 'involve students in actively finding knowledge, interpreting results, and testing hypotheses against reality (often in a spirit of cooperation as well as individual effort) as a route to understanding and the secure retention of factual knowledge' (Ramsden, 1992, p. 152).

According to Ramsden there is no best teaching method. Nevertheless, some methods naturally encourage a deep-holistic approach to learning better than others. The traditional university lecture tends to be modelled on an implicit theory of teaching as transmitting information to students 
rather than one of making learning possible. While lectures can be engaging, stimulating and can involve students as active learners, this is often difficult to achieve and more often they encourage surface-atomistic approaches to learning: students struggle to remember various isolated details and the lecturer appears as a remote authority rather than participating in a community of learning with his or her students. Consequently, Ramsden (1992, p. 167) insists that the best way to improve the effectiveness of teaching in higher education is to make lecturing 'less like a lecture (passive, rigid, routine knowledge transmission) and more like an active communication between teacher and students'.

In contrast to lecturing, role playing naturally tends to promote a deepholistic approach to learning because it requires students to interact and collaborate in order to complete an assigned task. The context of the role play requires students to adopt different perspectives and think reflexively about the information they represent to the group. Some benefits of role playing identified by historian James Levy (1997, pp. 14-18) are that it: helps overcome students' inhibitions to contribute because they feel that they do not know enough; stimulates student discussion and debate outside of the classroom; provides many teachable moments by revealing gaps in students' understanding that the instructor can address; encourages students to grapple with sophisticated issues that they might otherwise have failed to appreciate; and often challenges the teacher's own views.

Nira Hativa (2000, p. 122) outlines the following stages, according to which a role play should be structured:

1 establish the context and setting for the role play through a short lecture; 2 divide the class into a number of small groups and assign each group a different task, which it is to undertake according to a clearly delineated role; 3 provide time in class for each small group to plan and rehearse the role they have been assigned to act out in front of the class;

4 assign a time for each group to make a presentation to the whole class. Class members should then be able to identify and discuss the relevant issues and ideas from the act;

5 discuss the presentations made by different groups, showing assertive leadership and referring to the presentations of various groups in the following lecture.

During a role play the teacher acts not so much as a presenter of information but as a 'designer, choreographer, orchestrator and manager of the learning environment and teaching process' (Hativa, 2000, p. 111). As Hativa (2000, p. 111) observes, role playing is a riskier method of teaching than lecturing because it 'may introduce some chaos in the classroom and may lead to some uncertain learning outcomes'. In particular, misinformation often circulates during a role play. Fellow students may correct some of this. However, as Levy (1997, p. 18) points out, the teacher should resist the temptation to point out every inaccuracy since if 
students are worried about being criticised they tend not to venture their ideas freely. But, given this limitation of role playing, it is important to combine such student-centred instructional methods with more traditional techniques, such as a mini-lecture, in order to strike the right balance between independent and structured learning.

\section{A role play based on 'Five Fables of Human Rights'}

In the article on which the role play I devised is based, Lukes (1993) describes five ideal societies that are organised in accordance with the principles of justice advanced within five philosophical traditions: utilitarianism, communitarianism, socialism, libertarianism and egalitarianism. Lukes imagines each of these ideal societies as a country named according to its ruling political ideology. He takes the reader on a tour through each country in order to show the deficiencies of conceptions of justice that are not rights-based (Utilitaria, Communitaria and Proletaria) or focus only on formal rights (Libertaria). He argues that human rights are best understood in terms of his own favoured egalitarian conception of justice (Egalitaria). However, given the controversial nature of human rights (in view of the five competing traditions) and what he calls the communitarian constraint (people are inclined to give preferential treatment to co-members of a group) and the libertarian constraint (markets are necessary to produce prosperity but also tend to create social inequalities), Lukes doubts that Egalitaria can be realised anywhere in the world. Consequently, he concludes, 'the list of human rights should be kept both reasonably short and reasonably abstract' (Lukes, 1993, p. 38).

My aim in devising a role play based on Lukes's article was to familiarise students with these five traditions of political philosophy and the implications of each for how we should conceptualise human rights. Moreover, I wanted students to examine critically how plausible Lukes's claim is that it is possible to devise a short and abstract list of human rights that could become the object of an overlapping consensus among these competing traditions. Following the scenario cited at the beginning of this article, the exercise distributed in class went on:

In order that agreement might be possible between the five states that will form the Republic, the Egalitarians have recommended that the list of human rights contained within the declaration should be kept both reasonably short and reasonably abstract.

To this end, your delegation should draft a list of the FIVE most basic human rights that citizens of your country would be prepared to endorse. The list you come up with should reflect the ideology of your government. You may take the now defunct 1948 UN declaration of 
human rights as a starting point from which to select/modify the five human rights of your draft declaration. You must give reasons: 1) why your fellow citizens endorse these; and 2) why the other states within the new federation ought to.

Within your group you should assign: 1) someone to chair the meeting; 2) a minute taker; 3) a time keeper; 4) two representatives to make the case for your draft declaration at the inaugural meeting of the Federal Republic of Earth (FRE). The first representative should give reasons at the FRE why citizens of your country endorse the draft (i.e. in terms of your own conception of justice). The second representative will make the case for why other countries should vote for your draft declaration. The meeting of the FRE will commence at 15.00 in Lecture Theatre H7, Menzies Building, Monash University on the neutral (because politically weak) territory of Egalitaria.

Agenda for Inaugural Meeting of the Federal Republic of Earth, 6 May 2050

15.00 Welcome by the President of Egalitaria

15.05 Utilitarians present their draft declaration, followed by objections and amendments

15.15 Libertarians present their draft declaration, followed by objections and amendments

15.25 Proletarians present their draft declaration, followed by objections and amendments

15.35 Communitarians present their draft declaration, followed by objections and amendments

15.45 General deliberation followed by vote

In organising the two hour seminar, I followed Hativa's suggested structure:

1 Students had been assigned the Lukes article as required reading for this session. At the beginning of the seminar, I distributed copies of the UN Universal Declaration of Human Rights. In a 20-minute mini-lecture I discussed some of the different kinds of rights contained within the UN declaration of human rights (civil rights, welfare rights and cultural rights) and briefly outlined some of the disagreements about which rights should be included as basic human rights and how these should be interpreted (e.g. the idea that negative rights are more basic than positive rights).

2 I then distributed four different versions of the role play, each of which identified the reader as a member of one of four countries (Libertaria, Communitaria, Proletaria or Utilitaria). After allowing a few minutes for 
students to read the scenario, I explained the two main objectives of the session (stated above). ${ }^{2}$

3 Students then divided into their four groups and had 30 minutes to draft a list of the five basic rights that their citizens would be prepared to endorse. Each group was provided with a transparency sheet and marker on which to record their list of rights. I was available to provide advice about how the delegates' fellow citizens were likely to respond to their proposals.

4 When the four groups came back together for the inaugural meeting of the Federal Republic of Earth, I took the role of the president of Egalitaria who chaired the meeting. Each delegation gave a five-minute presentation after which they took questions from the floor. Members of other delegations raised objections to various proposals based on their own country's ideological commitments. As chair I was able to interject to ask for points of clarification, to keep some order to the debate and to ensure that the meeting ran on schedule.

5 I ended the session by taking a vote on the various proposals. This provided a neat way of returning to material covered earlier in the course on different methods of voting (Condorcet's majoritarian rule and Borda's positional rule), their susceptibility to strategic voting and the problem of cyclical majorities and the impact of factions.

\section{The merits of using role play to teach political theory}

To what extent did the use of this role play exemplify Ramsden's six principles of effective teaching?

1 Interest and explanation: There was a high level of energy and excitement during the seminar, particularly when the delegations met to discuss and vote on their proposals. After overcoming some initial reservations about what seemed like 'dumbed-down' teaching, most students were soon engrossed in getting to grips with the material, whether or not they had read Lukes's article.

2 Concern and respect for students and student learning: Using the role play encouraged students to express ideas in terms of the concepts associated with the particular ideology they were asked to engage with. A particular advantage of the role play was that it enabled students to learn from each other; students with different levels of competence in political theory benefited from the questions and explanations that they gave to each other. Moreover, the teacher naturally assumes a generous disposition in this situation as students ask for advice, help, clarification, etc. throughout the session.

3 Appropriate assessment and feedback: The role play provided immediate opportunities to provide students with feedback on their ideas. Like 
Levy, I tended not to correct misinformation. However, I did reward students by pointing out when a particularly good point was being made. I also recorded the meeting so that students could listen to the discussion later and I posted the various draft declarations of human rights on the subject website.

4 Clear goals and intellectual challenge: When devising the role play I was forced to articulate the learning outcomes I hoped to achieve more clearly than I had done when preparing regular lectures. This may have been related to the high-risk nature of this teaching method and my worry that students would not take it seriously if they could not see the point of it. A particular advantage of this teaching method is that it posed an intellectual challenge to students, regardless of their level of competence in the subject.

5 Independence, control and active engagement: Students had a high level of control over their own learning throughout the seminar. The most obvious alternative to the role play would have been to present the main arguments about human rights within each tradition - probably in bullet points on overhead transparencies - while students took notes. Clearly, getting students to articulate these for themselves was both a more effective and more efficient way for them to become familiar with these concepts.

6 Learning from students: This was the most personally rewarding aspect of the seminar. There were many 'teachable moments' in which gaps in students' understandings appeared that I was able to address, when it was possible to relate the present material to discussions in earlier seminars and to anticipate ideas that I planned to introduce later in the course. After the seminar, I was buzzing with ideas about how to improve the way I had presented material in previous lectures and how I might further develop the role play.

While every subject has its jargon, the object of study in political theory is the jargon itself. Perhaps because of its abstract nature, political theory often polarises politics students: it either alienates or inspires them. Role playing offers one valuable technique to overcome this divide by demonstrating in practice why we cannot do without theories of politics. By participating in this role play, students experienced at first hand how arguments made from within five traditions of political philosophy come into conflict in relation to the issue of human rights. Even self-avowed pragmatists have their own theories - only they are implicitly assumed rather than explicitly articulated. In role playing the pragmatists' selfdeception is exposed: they are forced to declare their (imagined) hands and hold their (assigned) theories open to scrutiny. Once drawn into the game, in this way, they are on their way to becoming political theorists. 


\section{Notes}

1 Thanks to the staff at the Centre for the Study of Higher Education at the University of Melbourne (Gabrielle Baldwin, Richard James, Kerri-Lee Krause and Craig McInnis) for inspiring me to try out this role play, and to Arna Marjanovic and three anonymous referees for their comments on an earlier draft of the article.

2 At this point, it was important to mention that although in Lukes's article there are no human rights in Communitaria, Utilitaria or Proletaria, it is not the case that these ideologies are incompatible with rights-based thinking. Rather, since they are teleological theories, they can support rights insofar as they promote their particular conception of the good.

3 While this exercise was developed for a two-hour seminar, it occurs to me that it might easily be used to integrate tutorials and lectures within one teaching week. In the first one-hour lecture of the week, the UN Declaration of Human Rights would be introduced, with the role play distributed towards the end of the lecture. Students would then draft their bill of rights in tutorials. The second one-hour lecture of the week would be used for the actual role play.

4 When using the exercise in future, I intend to make a visual recording of the session to be reviewed in the final week of the course. I will also link the exercise to an assessed expository exercise on Marx, Bentham or Burke's critique of rights.

\section{References}

Hativa, N. (2000), Teaching for Effective Learning in Higher Education, Dordrecht: Kluwer Publishers.

Lukes, S. (1993), 'Five Fables of Human Rights' in S. Shute and S. Hurley (eds.), On Human Rights: The Oxford Amnesty Lectures 1993, New York: Basic Books.

Levy, J. (1997), 'Getting Into the Skins of Historical Roles' in R. Ballantyne, J. Bain and J. Packer (eds.), Reflecting on University Teaching: Academics' Stories, Canberra: AGPS.

Ramsden, P. (1992), Learning to Teach in Higher Education, London and New York: Routledge. 


\section{University Library}

\section{- M M N E R VA A gateway to Melbourne's research publications}

Minerva Access is the Institutional Repository of The University of Melbourne

Author/s:

Schaap, Andrew

Title:

Learning political theory by role-playing

Date:

2005-02

Citation:

Schaap, A. (2005). Learning political theory by role-playing. Politics, 25(1), 46-52.

Publication Status:

Published

Persistent Link:

http://hdl.handle.net/11343/34373 